Please do not remove this page

RMIT

UNIVERSITY

\title{
Who trades profusely? The characteristics of individual investors who trade frequently
}

Richards, Daniel; Willows, Gizelle

https://researchrepository.rmit.edu.au/esploro/outputs/9921860618501341/filesAndLinks?institution=61RMIT_INST\&index=null

Richards, D., \& Willows, G. (2018). Who trades profusely? The characteristics of individual investors who trade frequently. Global Finance Journal, 35, 1-11. https://doi.org/10.1016/j.gfj.2017.03.006

Document Version: Submitted Version

Published Version: https://doi.org/10.1016/j.gfj.2017.03.006

Repository homepage: https://researchrepository.rmit.edu.au (C) 2017 Elsevier Inc. All rights reserved.

Downloaded On 2023/04/26 22:15:48 +1000 
Thank you for downloading this document from the RMIT Research Repository.

The RMIT Research Repository is an open access database showcasing the research outputs of RMIT University researchers.

RMIT Research Repository: http://researchbank.rmit.edu.au/

\section{Citation:}

Richards, D and Willows, G 2017, '(In Press) Who trades profusely? The characteristics of individual investors who trade frequently', Global Finance Journal, pp. 1-11.

See this record in the RMIT Research Repository at:

https://researchbank.rmit.edu.au/view/rmit:42627

Version: Submitted Version

Copyright Statement: (c) 2017 Published by Elsevier Inc.

Link to Published Version:

https://researchbank.rmit.edu.au/view/rmit:42627 


\title{
Who Trades Profusely? The characteristics of frequent trading individual investors
}

\begin{abstract}
:
Research has shown that investors trade too frequently and that this overtrading lowers investment return. This paper examines the characteristics of those investors that trade frequently. Using over three years of trading data of 7200 investors at a brokerage firm in the UK, descriptive statistics and multiple regression analyses were able to identify the predictive characteristics of investors that trade often. Most noteworthy is that trading frequency is positively skewed resulting in a small proportion of investors doing the majority of the trading with the highest cumulative value. These frequent trading investors tend to be male, younger and make use of multiple mediums of trading to trade. These mediums include the internet, the telephone, an advice team and use of stop losses.
\end{abstract}

Keywords: trading frequency; gender, age; trading medium;

JEL codes: G11, G12

\section{Daniel Richards ${ }^{\mathrm{a}}$}

Daniel Richards is a Lecturer of Wealth Management in the School of Accounting at RMIT University, Australia. His research interests are investor decision making and behavioural finance.

\section{Gizelle D. Willows ${ }^{\mathrm{b}}$}

Gizelle Willows is a Senior Lecturer of Accounting and doctoral candidate in Finance at the University of Cape Town, South Africa. Her research interests are retirement savings and behavioural finance.

\footnotetext{
${ }^{a}$ RMIT University, Melbourne, Australia

${ }^{\mathrm{b}}$ College of Accounting, University of Cape Town, South Africa
}

\section{Corresponding author and present address:}

Daniel Richards

RMIT University, Building 80 Level 9, 445 Swanston Street, Melbourne, VIC 3000, Australia

Ph: +61 39925 5935, Fax: +61 399255624 Email: daniel.richards@rmit.edu.au

Funding \& CoI: This research did not receive any specific grant from funding agencies in the public, commercial, or not-for-profit sectors. The authors have no actual or potential conflict of interests that could inappropriately influence, or be perceived to influence, their work. 


\title{
Who Trades Profusely? The characteristics of frequent trading individual investors
}

\begin{abstract}
Research has shown that investors trade too frequently and that this overtrading lowers investment return. This paper examines the characteristics of those investors that trade frequently. Using over three years of trading data of 7200 investors at a brokerage firm in the UK, descriptive statistics and multiple regression analyses were able to identify the predictive characteristics of investors that trade often. Most noteworthy is that trading frequency is positively skewed resulting in a small proportion of investors doing the majority of the trading with the highest cumulative value. These frequent trading investors tend to be male, younger and make use of multiple mediums of trading to trade. These mediums include the internet, the telephone, an advice team and use of stop losses.
\end{abstract}

Keywords: trading frequency; gender, age; trading medium;

JEL codes: G11, G12 


\section{Introduction}

Behavioural finance research has identified that some individual investors adopt investment strategies which are detrimental to their own performance. Research has shown that individual investors hold under-diversified portfolios (Goetzmann \& Kumar, 2008), trade too frequently (Odean, 1999) and are reluctant to sell losses while being eager to sell gains (Shefrin \& Statman, 1985). The focus of this paper is the trading frequency of investors because trading costs, such as commission and the bid-ask spread, have a direct impact on the portfolio returns on investors (Barber \& Odean, 2000). With literature highlighting the negative impact of such overtrading, the need to determine who is most susceptible to overtrading is necessary. This study fills this need by examining the characteristics of those investors that trade frequently in a sample of UK investors. Using over three years of trading records of 7200 investors at a brokerage firm, we identify the characteristics of investors that trade frequently.

One contribution of this research is that we highlight that trading frequency is not evenly distributed across our investors. Trading frequency is positively skewed with a few investors (10\%) trading very frequently and a majority of investors (90\%) trading less frequently. Furthermore, as investors who trade less frequently buy more then they sell, suggesting they are more inclined to adopt a buy and hold strategy. A second contribution of this paper is we identify that female investors and older investors trade less frequently. In addition, investors who trade frequently use both the internet and telephone to trade, are more likely to trade using an advisor and are more likely to use stop losses. These findings are of relevance for investors and policy makers as it suggest that strategies to reduce investors trading frequency need be targeted at a minority of investors. The findings also suggest that trading frequency is an aspect of learning amongst investors because younger investors, those using an advice team and those adopting a stop loss strategy are trading more.

\section{Literature review}

This literature review begins by discussing the notion of trading frequency. Following from that, the characteristics of investors that trade frequently are presented.

\subsection{Trading frequency}

The amount of trades completed by investors has become an anomaly amongst behavioural science research because investors overtrading is detrimental to investor performance (Daniel \& Hirshleifer, 2016). Baker (2010) argues that investors obtain below-benchmark performance as a result of frequent trading. This occurs because individuals trade stock in a different manner to that expected by neo-classical models of a rational investor. Research supports Baker's (2010) argument. In a seminal paper, Odean (1999) found that the trading volume of a particular class of investors, those with discount brokerage accounts, was found to be excessive because the costs of trading exceed profits earned from trading. Similarly, Barber and Odean (2000) found that the investors who traded the most (top quintile) earned an annual return of 11.4 per cent, compared to the market's 17.9 per cent. 
A more recent study of 19,021 individuals from a South African investment house over the five year period from 1 January 2007 to 31 December 2011 was carried out by (Willows \& West, 2015a). The study evaluated the trading behaviour, returns and variances in returns earned by investors. The results were consistent with those of Barber and Odean (2000), confirming that a statistically significant negative correlation exists between trading frequency and investor returns (Willows \& West, 2015a). Marszalek (2014) and Junor (2014) also find a statistically significant negative correlation between the number of trades made by investors and their respective returns. A similar negative relationship between returns and trading volume was also shown in a simulated stock investment system in China by Zhang et al. (2014). Overall, robust evidence supports that trading frequently lowers the returns investors earn on their investments, due to transactions costs and the bid-ask spread. Prudent advice is that investors should buy and hold investments, as opposed to regularly trading their investments in order to maximise their return (Barber \& Odean, 2013; Junor, 2014; Marszalek, 2014; Willows \& West, 2015a). Barber and Odean (2013) warn that those individual investors who disregard the narrow advice to buy and hold low-fee, welldiversified portfolios, are doing so to their own detriment.

\subsection{Who trades frequently?}

With the link between high trading frequency and poor returns being demonstrated, research is now needed that identifies those investors who trade more frequently so that policies can be implement to address this behaviour. One argument presented in academic literature on the cause of overtrading by individual investors is that these investors are overconfident. Here we briefly review literature on overconfidence and investor trading frequency in order to derive characteristics of investors who trade frequently.

Overconfidence can be separated in three facets; overconfidence about the certainty of information (miscalibration), overconfidence about ability (better-than-average effect) or overconfidence about performance on certain tasks (overestimation) (Moore \& Healy, 2008). Whilst miscalibration is purported as the cause of overtrading (Daniel, Hirshleifer, \& Subrahmanyam, 1998), studies have also shown this aspect of overconfidence, as measured by calibration questions, is unrelated to trading volume (Fellner-Röhling \& Krügel, 2014; Glaser \& Weber, 2007). Research has found that the better-than-average effect has more of an influence on trading frequency. Graham et al. (2009) argue that investors who believe that they are more knowledgeable or skilful in making decisions of a financial nature, will be more willing to act on those decisions. Therefore, investors who feel more competent, trade more frequently than those investors that feel less competent. This argument is supported by Glaser and Weber (2007) who found that investors who think they are above average in terms of their past performance and/or investment skills, trade more.

\subsubsection{Gender}

Some research that uses gender as a proxy for overconfidence supports that competence is related to trading frequency. Male investors are more overconfident than female investors because they expect higher portfolio returns (Barber \& Odean, 2001) and rate their skills more highly (Deaves et al., 2009). Barber and Odean (2001) and Deaves et al. (2009) found 
that males trade more frequently than women. However, other research has shown that gender does not influence trading volume (Glaser \& Weber, 2007) indicating that more analysis is needed on this topic. We hypothesize the following:

H1: Men will trade more frequently than women.

\subsubsection{Age}

Another variable related to overconfidence is an investor's age. Theoretical models predict that overconfidence increases with experience as investors learn to be overconfident (Gervais \& Odean, 2001). This suggests that as investors get older and more experienced they will trade more frequently. However, Korniotis and Kumar (2011) found that an investor's age was negatively related to trading frequency in a study of US investors. This is contrary to Willows (2014) who showed trading frequency to increase as investors got older. Willows (2014) hypothesised that as investors get older, they might be switching to lower-risk funds or claiming annuities, thereby increasing their trading frequency. We hypothesize the following:

H2: Younger investors will trade more frequently than older investors.

\subsubsection{Medium of trade}

Certain literature has credited the emergence of internet based trading to have played a part in increased trading. Whereas telephone trading has its limitations, electronic trading removes all geographical restraints. As a result, higher volumes of trades can be handled (Allen, Hawkins, \& Sato, 2001). Choi, Laibson and Metrick (2002) showed trading frequency to double after 18 months of internet access. In an attempt to understand the characteristics of those trading over the internet (rather than the telephone), the results showed young, wealthy, male investors to use this medium (Choi et al., 2002). Similar research on adoption of internet trading in developing countries found that younger investors are more likely to adopt internet trading (Singh, Sandhu and Kundu 2010). Also, Barber and Odean (2002) showed that those investors who switched from a telephone based trading account to an internet account traded more frequently and less profitability than those who did not switch. Barber and Odean (2002) interpet these results to show that overconfidence influences trading volume because investors who switch will be more prone to overconfidence. Whilst these studies show a clear distinction between trading frequency and early adoption of the internet to trade, it is unknown whether this relationship still holds now that internet trading is common practice. We research the link between trading frquency and the use of the internet and telephone mediams to trade and hypothesize the following:

H3: Investors who use the internet to trade will trade more than investors who do not use the internet to trade.

H4: Investors who use the telephone to trade will trade less than investors who do not use the telephone to trade. 


\subsubsection{Use of an advice team}

Another variable associated with increased trading frequency is use of an advice team to inform trading decisions. Use of advice could be seen as an undertaking by inexpert investors but research has found that investors who believe they are more competent are more likely to engage in advisory services (Bhandari \& Deaves, 2006). Furthermore, research into investors trading of funds suggests that investors who receive advice trade more than investors who do not. Using data from a specific equity fund of a South African investment house over the period from 1 January 2006 to 31 December 2014, Allie, West and Willows (2016) showed that advised investors enter or exit their funds more often than non-advised investors. However, the increased trade frequency by advised investors did not translate into any significant difference in the returns earned. We expect that investors who receive advice will trade more than investors who do not. Our hypothesis is:

H5: Investors who use the advice team to trade will trade less than investors who do not use the advice team to trade.

\subsubsection{Stop losses}

The final factor investigated in relation to investors' trading frequency is investor's use of stop losses. Stop losses are a type of automatic trading strategy where stock will be sold automatically if its price drops to a level predetermined by the investor. Stop losses need to be set by investors but the trade is executed by the brokerage firm on their behalf. To the authors' knowledge, there is no literature on the relationship between stop loss use and trading frequency. However, there is literature associating stop loss use with sophistication and propensity to bias. Nolte (2012) argues that investor who use stop losses could be sophisticated because an investor acknowledges that he/she cannot predict the market and therefore uses stop losses to mitigate against this inability. However, stop losses could be used by investors that are less sophisticated in that they are uniformed about future price movements. Richards et al. (2015) researched the use of stop losses by investors to mitigate a behavioural bias called the disposition effect, where investors hold losses and sell gains. Richards et al (2015) find that investors who use stop losses tend to be younger and more susceptible to the disposition effect when not using stop losses. For our research, we argue that use of stop losses by investors is linked to a strategy of managing risk by exiting the market when prices drop. Such a strategy could be adopted by less experienced investors but would lead to them trading more. We hypothesize that:

H6: Investors who use stop losses will trade more frequently than investors who do not use stop losses.

\section{Methodology and data}

Trading data was obtained from a brokerage firm in the United Kingdom (UK). The brokerage firm provides their clients with the means to trade stocks in the UK stock market via the internet, telephone, written correspondence and in person. The brokerage firm specialises providing a trading platform to individual investors for trading of stock and does not offer any other trading service (e.g. currency trading, options etc.). The vast majority of 
investors could only take long positions in the market and less than $1 \%$ of investor could take a leveraged position by trading warrants. The firm had approximately $6 \%$ market share of the total UK brokerage industry at the end of 2009. Trading records were provided for 7829 investors who completed a total of 395998 trades over a period from 4 July 2006 to 14 December 2009 ('the period'). These investors were selected randomly by the sales manager at the brokerage. Overall, the investors in this sample can be generalised to those UK based individual investors that are actively trading in shares, funds and bonds. The trading records contained information about the gender and age of each investor, as well as their trading behaviour.

The data was filtered for analysis. Investors who did not have age or gender data were removed as they could not be used in our analysis. Also, investors younger than 19 were removed as these investors may not be making their own investment decision (Willows \& West, 2015b). This filtering removed 628 investors who had completed 23548 trades. Therefore, the final sample to be tested consisted of 7200 investors who completed 372449 trades over the period.

From the filtered trading data, trading based and investor based variables were derived for analysis purposes. Here these variables are defined to illustrate how each was calculated but descriptive statistics with more details are provided in sub-sections 3.1 and 3.2.

Trading frequency: This variable is a natural log transform of the number of trades completed by an investor over the sample period.

Gender: The gender of the investor is included as a binary dummy variable where one indicates a male investor and zero indicates a female investor.

Age: The age of the investor as a whole number in years at 14 December 2009 (the last trading day in the period) and is included as a continuous variable.

Internet user: This is a dummy variable that takes the value of one if an investor traded using the internet and zero otherwise.

Telephone user: This is a dummy variable that takes the value of one if an investor traded using the telephone and zero otherwise.

Advice team user: This is a dummy variable that variable takes the value of one if an investor traded using the advice team and zero otherwise. An advice team trade refers to those trades that were conducted by advisors working at the brokerage firm, on behalf of investors. Investors could contact an advisor at the brokerage firm for free (via the telephone or in person) and these advisors could execute trades on behalf of investors.

Stop loss user: This is a dummy variable that takes the value of one if an investor sold stocks using a stop loss and zero otherwise. Stop loss transactions involve an investor placing a limit order transaction to sell stock if that stock's price decreases by an amount predetermined by the investor. All stop loss transactions are set via the internet in this data.

Automatic reinvestment user: This is used as a control variable as it is likely to increase trading volume. Automatic reinvestment trades refer to an investment strategy chosen by investors, where their dividends are collected by the brokerage firm and then automatically 
used to purchase more shares on their behalf. It takes the value of one if an investor had an automatic reinvestment trade or zero otherwise.

It is important to note that the investor variables for the medium used to trade (internet user, telephone user, advice team user and automatic reinvestment user) are not mutually exclusive. An investor could use one or more of these mediums to trade stocks.

\subsection{Descriptive statistics}

Descriptive statistics of the investors and the medium used to trade are outlined in Table 1.

Table 1: Descriptive statistics per investor

\begin{tabular}{|c|c|c|c|c|c|}
\hline Investor & Mean & $\begin{array}{l}\text { Standard } \\
\text { deviation }\end{array}$ & $\begin{array}{c}25^{\text {th }} \\
\text { Percentile }\end{array}$ & Median & $\begin{array}{c}75^{\text {th }} \\
\text { percentile }\end{array}$ \\
\hline Mean trade value* & $\$ 2188.53$ & $\$ 3293.18$ & $\$ 614.03$ & $\$ 1198.46$ & $\$ 2515.62$ \\
\hline Number of trades & 51.72 & 93.67 & 13 & 26 & 55 \\
\hline Age & 54.11 & 13.70 & 44 & 55 & 64 \\
\hline $\begin{array}{l}\text { Number of internet } \\
\text { trades }\end{array}$ & 40.14 & 86.50 & 0 & 16 & 42 \\
\hline $\begin{array}{l}\text { Number of telephone } \\
\text { trades }\end{array}$ & 5.35 & 32.98 & 0 & 0 & 2 \\
\hline $\begin{array}{l}\text { Number of advice } \\
\text { trades }\end{array}$ & 0.42 & 2.81 & 0 & 0 & 0 \\
\hline $\begin{array}{l}\text { Number of auto- } \\
\text { reinvestment trades }\end{array}$ & 4.31 & 10.59 & 0 & 0 & 3 \\
\hline \multirow[t]{2}{*}{$\begin{array}{l}\text { Number of stop loss } \\
\text { trades }\end{array}$} & 1.22 & 7.07 & 0 & 0 & 0 \\
\hline & Male & Female & & & \\
\hline $\begin{array}{l}\text { Gender n } \\
\% \text { of all investors }\end{array}$ & $\begin{array}{c}5616 \\
78 \%\end{array}$ & $\begin{array}{c}1584 \\
22 \%\end{array}$ & & & \\
\hline
\end{tabular}

* calculated as total value traded in GBP/ number of trades per investor

The mean and median value in British pounds traded per trade per investor was $£ 2188.00$ and $£ 1$ 198.46, respectively. The standard deviation of $£ 3293.18$ indicates that the amount traded is positively skewed. Likewise, the number of trades completed per investor is also positively skewed with a mean of 51.72 trades, a median of 26 and a standard deviation of 93.67. Overall, there are a few investors who trade very frequency and many investors who trade less frequently. The skewed nature of trading frequency is developed more in subsection 3.2. There are 5,616 male investors and 1,584 female investors in the sample and the age of these investors ranged from 19 to 101, with a mean of 54.11, median of 55 and standard deviation of 13.7.

An overview of the percentage of trades conducted via each medium is outlined in Figure 1. 


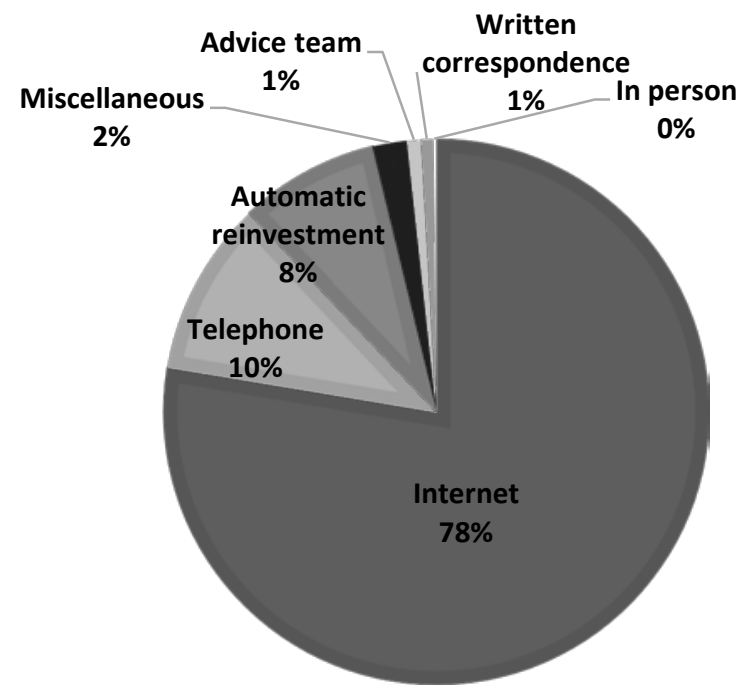

Figure 1: Percentage of trades conducted via different mediums

Over three quarters of the trades occurred via the internet. The second most popular trading medium was telephone trades (10\% of trades), followed by automatic reinvestments ( $8 \%$ of trades). Advice team, written correspondence and in person trades were used infrequently. Finally, miscellaneous trades represent all other trades and include trades completed via an application form or shareholding certificate.

Age based differences of investors are outlined in Table 3. The first column lists the gender of the investor and the different mediums of trading. The second and third columns then calculate the mean age of the sample of investors who did or did not use that medium. For the gender of the investor, the second column presents the mean age of investors who were male, while the third column gives the mean age of investors who are not male i.e. female. The fourth and final column reports the t-values from an independent t-test. 
Table 3: Age differences in gender and trading mediums

\begin{tabular}{|l|c|c|c|}
\hline & $\begin{array}{c}\text { Mean age } \\
\text { Yes }\end{array}$ & $\begin{array}{c}\text { Mean age } \\
\text { No }\end{array}$ & t-value \\
\hline Male investor & 53.64 & 55.74 & $5.40^{* * *}$ \\
$\mathrm{~N}$ & 5616 & 1584 & \\
\hline Internet user & 53.09 & 61.88 & $17.76^{* * *}$ \\
$\mathrm{~N}$ & 6370 & 830 & \\
\hline Telephone user & 56.87 & 52.05 & $-15.02^{* * *}$ \\
$\mathrm{~N}$ & 3064 & 4136 & \\
\hline Advice team user & 62.20 & 53.59 & $-12.78^{* * *}$ \\
$\mathrm{~N}$ & 430 & 6770 & \\
\hline Stop loss user & 49.57 & 54.89 & $11.84^{* * *}$ \\
$\mathrm{n}$ & 1072 & 6128 & \\
\hline Automatic reinvestment user & 58.01 & 52.36 & $-16.44^{* * *}$ \\
$\mathrm{~N}$ & 2216 & 4984 & \\
\hline $\mathrm{a}^{* * *}=\mathrm{p}<.01$ & \multicolumn{3}{|l}{} \\
\hline
\end{tabular}

Table 3 indicates that male investors in the sample tend to be younger than female investors and those investors who traded via the internet are younger than those who do not. Conversely, use of the telephone to trade, use of the advice team and use of automatic reinvestment trades are adopted more frequently by older investors. Finally, investors that have made used of stop losses in the sample tend to be younger than investors who did not.

Gender based differences in the trading medium and use of stop losses are outlined in Table 4. Significance tests are conducted using a Chi2 test.

Table 4: Investor gender across dependent variables

\begin{tabular}{|ll|c|c|c|c|c|}
\hline & & Female & $\begin{array}{c}\text { \% of } \\
\text { female } \\
\text { investors }\end{array}$ & Male & $\begin{array}{c}\text { \% of } \\
\text { male } \\
\text { investors }\end{array}$ & Chi2 \\
\hline Internet user & Yes & 204 & $12.88 \%$ & 626 & $11.15 \%$ & $3.63^{*}$ \\
& No & 1380 & $87.12 \%$ & 4990 & $88.85 \%$ & \\
\hline Telephone user & Yes & 917 & $57.89 \%$ & 3,219 & $57.32 \%$ & 0.17 \\
& No & 667 & $42.11 \%$ & 2397 & $42.68 \%$ & \\
\hline Advice team user & Yes & 108 & $6.82 \%$ & 322 & $5.73 \%$ & 2.59 \\
& No & 1476 & $93.18 \%$ & 5294 & $94.27 \%$ & \\
\hline Automatic reinvestment user & Yes & 523 & $33.02 \%$ & 1693 & $30.14 \%$ & $4.78^{* *}$ \\
& No & 1061 & $66.98 \%$ & 3923 & $69.85 \%$ & \\
\hline Stop loss user & Yes & 160 & $10.10 \%$ & 912 & $16.23 \%$ & $36.74^{* * *}$ \\
& No & 1424 & $89.90 \%$ & 4704 & $83.76 \%$ & \\
\hline Total & 1584 & $100 \%$ & 5616 & $100 \%$ & \\
\hline$*=\mathrm{p}<.1, * *=\mathrm{p}<.05, * * *=\mathrm{p}<.01$ \\
\hline
\end{tabular}

There are statistically significant differences in gender for the use of the internet, automatic reinvestment trades and stop losses. Specifically, $12.88 \%$ of female investors use the internet to trade, but only $11.15 \%$ of men. Furthermore, 33\% of females use automatic reinvestment trades but only $30 \%$ of male investors do. For stop losses, $16 \%$ of male investors use these, 
but only $10 \%$ of female investors do. Differences in use of the telephone and advice team were not statistically significant at $\mathrm{p}<.05$ levels.

\subsection{Description of trading frequency}

The dependant variable in this analysis is how frequently an investor trades and the paper adopts a log transform of the number of trades completed per investor over the period. The reason for this is represented in Figure 2 which shows the distribution of investors based on the number of trades they completed over the sample period.

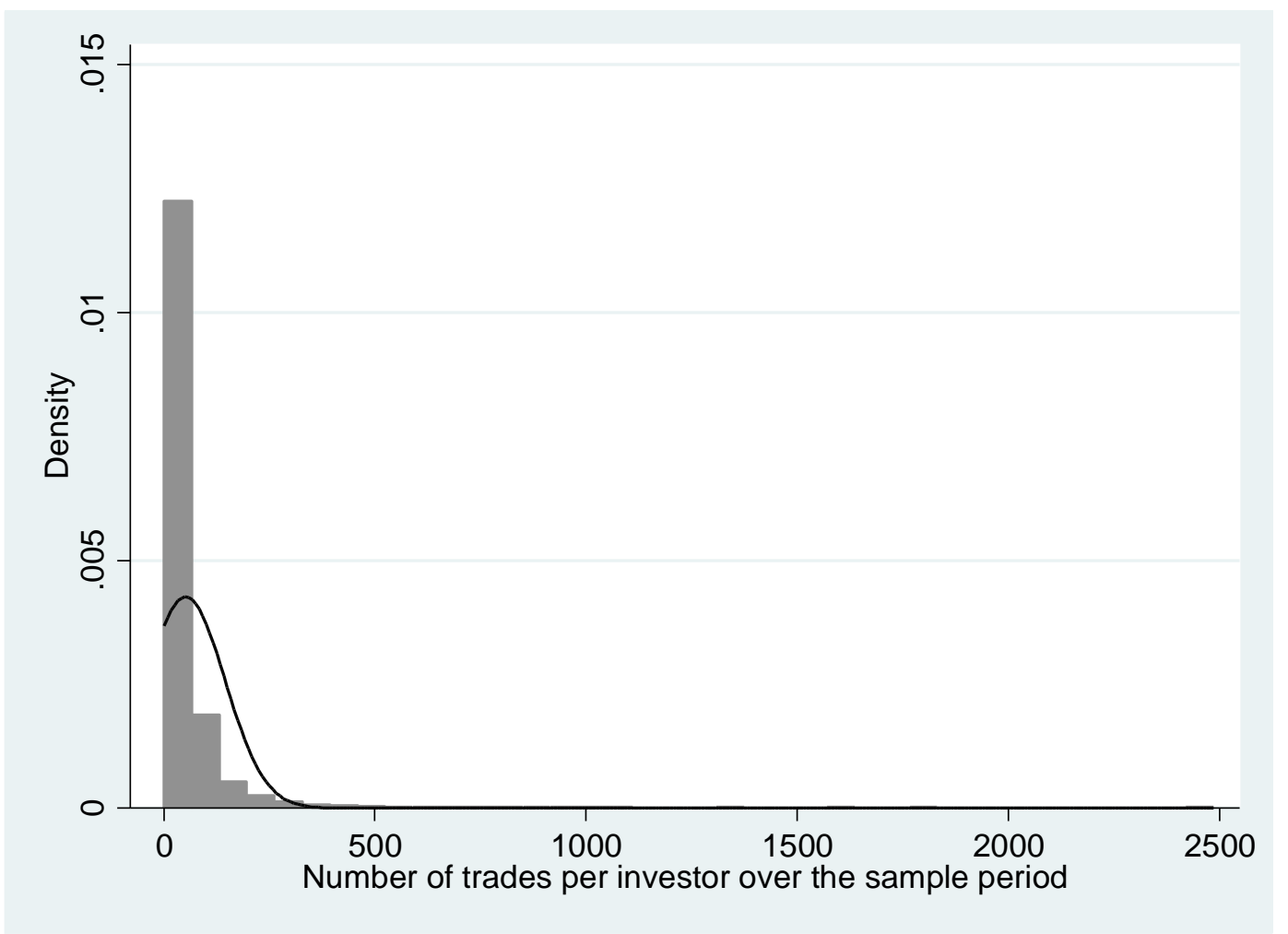

Figure 2: Distribution of number of trades per investor over the sample period

Figure 2 shows that trading frequency is positively skewed, with few investors trading greater than 250 trades over the period but most investors completing below this amount. Due to this skewness, a natural log transform on the number of trades per investor was performed to transform the dependent variable closer to the normal distribution required for multiple regression analyses. Figure 3 shows the log number of trades per investor over the sample and indicates that it is closer to a normal distribution. 


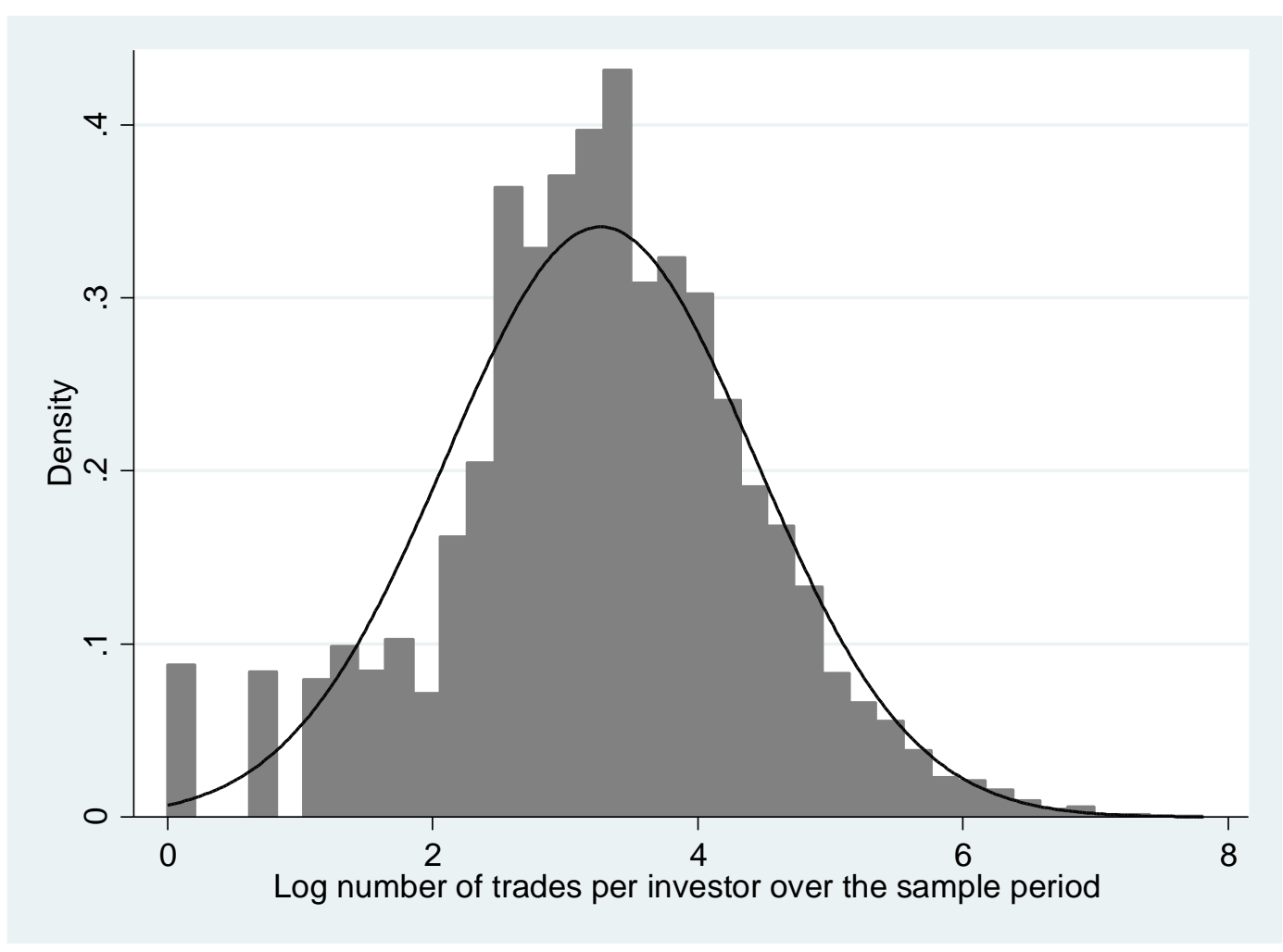

Figure 3: Distribution of log number of trades per investor over the sample period

There are a higher number of investors on the left side of the distribution than is expected in a normal distribution and this is controlled for in the multiple regression analysis in section 4 . Graphical tests of the normality assumption were adopted because the central limit shows convergence towards a normal distribution with large samples (n= 7200 in this paper) (Lind, Marchal, \& Wathen, 2005). Furthermore, a natural log transform of number of trades was also employed by Glaser and Weber (2007) and Grinblatt and Keloharju (2009) when researching trading frequency.

An argument presented in academic literature is that investor's trade too much and that trading causes underperformance. Instead, investors should adopt a buy and hold strategy in order to improve portfolio returns (Barber \& Odean, 2013). Whilst this theory is not challenged here, a picture that emerges from the data is that high trading frequency cannot be generalised to all investors. Statistics are presented in Table 5 to illustrate how trading frequency is spread across investors and the extent to which they adopt a buy and hold strategy vs. a buy and sell strategy. Table 5 shows statistics on investors separated by their number of trades into the 0 -80th percentile (least amount of trades), 80-90th percentile, and 90-100th percentile (most number of trades) to illustrate differences between investors based on how often they trade. 
Table 5: Investors by number of trades

\begin{tabular}{|c|c|c|c|}
\hline & $\begin{array}{l}0^{\text {th }}-\mathbf{8 0}^{\text {th }} \\
\text { percentile of } \\
\text { investors }\end{array}$ & $\begin{array}{c}80^{\text {th }}- \\
90^{\text {th }} \text { percentile } \\
\text { of investors }\end{array}$ & $\begin{array}{c}90-100^{\text {th }} \\
\text { percentile of } \\
\text { investors }\end{array}$ \\
\hline Number of investors & 5762 & 723 & 715 \\
\hline $\begin{array}{l}\text { Number of trades } \\
\text { (\% of total) }\end{array}$ & $\begin{array}{c}111331 \\
(32.79 \%)\end{array}$ & $\begin{array}{c}58108 \\
(17.11 \%)\end{array}$ & $\begin{array}{l}170103 \\
(50.10 \%)\end{array}$ \\
\hline $\begin{array}{l}\text { Mean trades per investor } \\
\text { Median trades per investor }\end{array}$ & $\begin{array}{c}19.67 \\
15\end{array}$ & $\begin{array}{c}80.24 \\
78\end{array}$ & $\begin{array}{c}237.90 \\
169\end{array}$ \\
\hline $\begin{array}{l}\text { Total value of trades } \\
\text { (\% of value of trades in dataset) }\end{array}$ & $\begin{array}{l}£ 230047309 \\
\quad(31.00 \%)\end{array}$ & $\begin{array}{l}£ 115123090 \\
\quad(15.51 \%)\end{array}$ & $\begin{array}{c}£ 396889032 \\
(53.48 \%)\end{array}$ \\
\hline $\begin{array}{l}\text { Number of purchases } \\
\text { (\% of trades that are purchases) }\end{array}$ & $\begin{array}{c}79909 \\
(71.78 \%)\end{array}$ & $\begin{array}{c}37860 \\
(65.15 \%)\end{array}$ & $\begin{array}{l}104481 \\
(61.42 \%)\end{array}$ \\
\hline $\begin{array}{l}\text { Total value of purchases } \\
\text { (\% of total value that are purchases) }\end{array}$ & $\begin{array}{l}£ 139847712 \\
\quad(60.79 \%)\end{array}$ & $\begin{array}{c}£ 64235753 \\
(55.80 \%)\end{array}$ & $\begin{array}{c}£ 209645934 \\
\quad(52.82 \%)\end{array}$ \\
\hline $\begin{array}{l}\text { Mean trade value per investor } \\
\text { Median trade value per investor }\end{array}$ & $\begin{array}{c}£ 1687.99 \\
£ 926.47\end{array}$ & $\begin{array}{l}£ 1925.49 \\
£ 1079.25\end{array}$ & $\begin{array}{l}£ 2349.14 \\
£ 1195.23\end{array}$ \\
\hline
\end{tabular}

The top ten per cent of the most frequently trading investors completed half of the number of trades (50.1\%) and just over half the value of trades (53.48\%) in the data set. These investors are very different compared to investors in the $80-90^{\text {th }}$ percentiles, who completed only $17.11 \%$ of trades or $15.51 \%$ of total value traded. This pattern is also replicated with the mean number of trades per investor, which is 237.90 (around 69 trades per annum) in the top per cent of most active investors, to 80.24 (around 23 trades per annum) in the $80-90^{\text {th }}$ percentiles and 19.67 (6 trades per annum) for the 0 to 80th percentile investors. This shows acute differences in the number of trades made between the most frequent trading decile and second most frequent trading decile of investors. These statistics highlight that excessive trading frequency seems to be adopted by a small proportion and that the majority of investors do not trade excessively.

The finding that trading frequency is positively skewed is not an atypical result as other studies on investors across the globe have skewed trading data. Here we cite some studies to illustrate this point. Using data from a brokerage firm in Germany, Glaser and Weber (2007) found that the mean number of trades is 184.89 and the median of 103 . With the mean much higher than the median, this indicates a positively skewed distribution. Similarly, in a study of Finnish investors, Seru, Shumway, and Stoffman (2010) report the mean number of trades per investor is 15.4 and the median 3. In South Africa, Willows and West (2015a) found that $77 \%$ of investors made no trades during a five year period and graphically presented a graph of the skewed distribution. Finally, Baber and Odean (2000) use a sample of United States of America investors and separate these investors into quintiles based on how frequently they trade. They report a mean monthly turnover for each quintile and show that the bottom (least frequent) trading quintile turns over $0.19 \%$ of their portfolio yet the top (most frequent) trading quintile turns over $21.49 \%$ of their portfolio, This also indicates a positively skewed 
distribution and adds to the evidence that extremely high trading frequency is completed by a few investors and the majority trade less in comparison.

We also investigate the extent to which investors are churning their portfolio or adopting a buy and hold strategy. As investor portfolio data was not available in our data, we cannot count the specific of amount of portfolio churning each investor did over the sample period. Nonetheless, indicative results can be shown by calculating the number of purchases as a percentage of total number of transactions and also the value purchased of as a percentage of total value traded for each investor. If an investor's percentage of purchase trades and percentage of value purchased is close to $50 \%$, it indicates that investors are churning their portfolio because they are purchasing as much stock as they are selling. Table 5 shows that for the $90-100$ th percentile of investors, $61.42 \%$ of their trades and $52.82 \%$ of the value traded were purchases. For the 0 -80th percentile of investors, $71.78 \%$ of their trades were purchases and $60.79 \%$ of the value of trades were purchases. These results suggest that the investors who trade more frequently are churning their portfolio to a greater extent than lower frequency traders.

\subsection{Model}

To test the research hypotheses, a multiple regression model was run using Stata 14.1. The multiple regression analysis has the log number of trades per investor as a dependent variable and the independent variables as outlined in section 3 . We run two multiple regression models which can be expressed as follows:

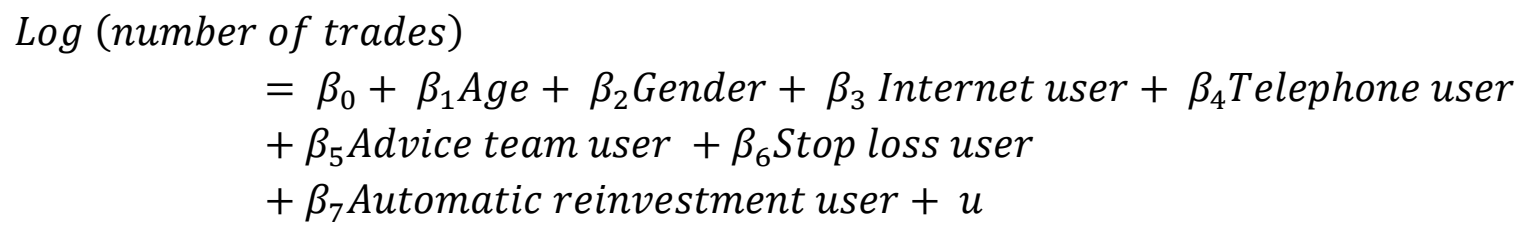

[Equation 1]

where $\beta_{0}$ is the intercept, $\beta_{1-7}$ are the parameters associated with the independent variable and $u$ refers to the factors that are not included in the model (Wooldridge, 2003). Model 1 contains all independent variables and is used to test our research hypotheses. Model 2 is a robustness check of the model following regression diagnostics. Regression diagnostics indicated small violations to the normality of residuals and heteroscedasticity due to a high number of traders completing 1 to 2 trades over the period. Due to these violations, we removed all investors who completed 2 or less trades to ascertain whether these investors were influencing our findings. Regression diagnostics for normality of residuals, heteroscedasticity, multicollinearity, non-linearity and model specification were normal once these investors had been removed.

\section{Results}

The results for our analysis are outlined in Table 6, with column 1 and column 2 containing the results for model 1 and model 2, respectively. 
Table 6: Multiple regression of log number of trades

\begin{tabular}{|l|c|c|}
\hline Variable & Model 1 & Model 2 \\
\hline Intercept & $2.353^{* * *}$ & $2.626^{* * *}$ \\
(Standard error) & $(0.075)$ & $(0.069)$ \\
\hline Age & $-0.005^{* * *}$ & $-0.004^{* * *}$ \\
(Standard error) & $(0.001)$ & $(0.001)$ \\
\hline Gender & $0.161^{* * *}$ & $0.143^{* * *}$ \\
(Standard error) & $(0.030)$ & $(0.028)$ \\
\hline Internet user & $0.641^{* * *}$ & $0.491^{* * *}$ \\
(Standard error) & $(0.043)$ & $(0.040)$ \\
\hline Telephone user & $0.505^{* * *}$ & $0.423^{* * *}$ \\
(Standard error) & $(0.027)$ & $(0.025)$ \\
\hline Advice team user & $0.200^{* * *}$ & $0.135^{* * *}$ \\
(Standard error) & $(0.055)$ & $(0.050)$ \\
\hline Stop loss user & $0.971^{* * *}$ & $0.869^{* * *}$ \\
(Standard error) & $(0.035)$ & $(0.032)$ \\
\hline Automatic reinvestment user & $0.451^{* * *}$ & $0.307^{* * *}$ \\
(Standard error) & $(0.027)$ & $(0.025)$ \\
\hline Adjusted r-squared & 0.187 & 0.166 \\
$N$ & 7200 & 6946 \\
\hline$*<.1, * *<.05, * * *<.01$ & \multicolumn{2}{|l}{} \\
\hline
\end{tabular}

Model 1 shows the relationship between trading frequency and the independent variables. The findings for gender indicate that male investors trade more frequently than female investors as the dummy gender variable has a positive relationship with log number of trades $(\mathrm{r}=0.161, \mathrm{p}<.01)$. This supports hypothesis 1 that men trade more frequently than women. Hypothesis 2, that younger investor's trade more frequently than older investors, is also supported because age has a negative relationship with log number of trades ( $\mathrm{r}=-0.005$, $\mathrm{p}<.01$ ). The demographic influence on trading frequency show that older and female investors trade less frequently than younger male investors.

In relation to the mediums used by investors, we find that investors who use the internet ( $\mathrm{r}=$ $0.641, \mathrm{p}<.01)$ and investors who use the telephone $(\mathrm{r}=0.505, \mathrm{p}<.01)$ both have a positive relationship with trading volume. This supports hypothesis 3 , that investors who use the internet to trade will trade more frequently than those who do not. However, hypothesis 4 which states that investors who use the telephone to trade will trade less than investors who do not use the telephone to trade, is not supported. This result is different to literature which has shown that investors who switch from using the telephone to trade to using the internet to trade, traded more frequently (Barber \& Odean, 2002). The previous research looked at early adopters of the internet as a trading mechanism, whereas, our sample period is when the internet is the most common method of trading. Our findings show that both the internet and the telephone mediums are used by frequent traders. An interpretation of these results is that investors who trade frequently will utilise multiple methods in order to trade securities.

Hypothesis 5 conjectured that investors who used an advice team to trade stocks would trade more frequently. The results support this hypothesis, showing that there is a positive relationship between those who use advice and log number of trades per investor $(r=0.200$, 
$\mathrm{p}<.01$ ). Looking at the stop loss use, the results support hypothesis 6 , that investors who use stop losses trade more frequently $(r=0.971, \mathrm{p}<0.17$ ). Finally, the control variable, automatic reinvestment user, also has a positive correlation with log number of trades. Overall, the adjusted r-squared value of 0.187 indicates the $18.7 \%$ of the variance in trading frequency is explained by these variables.

Model 2 contains the same variables as model 1, but has a smaller sample of investors as investors who traded 2 times or less were excluded because their inclusion violated the normality of residuals and heteroscedasticity assumptions in multiple regression analysis (refer to sub-section 4.3 for more details). The results in model 2 are of a similar nature to the results in Model 1. The main differences which occur are reduction in the $\beta$ values for all coefficients excluding the intercept and a reduction in the r-squared value from 0.181 to 0.166 . As the results between model 1 and model 2 are analogous, we conclude that the violations identified by the regression diagnostics mentioned in sub-section 4.3 , did not influence the results of this research.

In summary, the results suggest that male and younger investors are more likely to be frequent traders. Whilst trading via the internet is the most popular method, investors that trade frequently will also trade via the telephone. Use of the advice team and use of stop losses are both also associated with increased trading frequency.

\section{Discussion}

A key finding from behavioural finance research on aggregate individual investor behaviour is that they trade too frequently (Odean, 1999). This paper researched trading frequency as there is robust evidence that trading frequently is detrimental to investor's portfolio performance (Daniel \& Hirshleifer, 2016; Willows \& West, 2015a; Zhang et al., 2014). Thus, investors and policy makers will have clear reasons for curving this behaviour. Where previous research has focused on the relationship between trading frequency and overconfidence, this research focused on the characteristics of frequent traders. We do this so that the investors who trade frequently can be identified and policies to correct such behaviour can be targeted at the more likely susceptible investors.

One contribution of this research is that there are a few investors who trade very frequently and a lot of investors who trade less frequently. Our results showed that the number of trades per investor followed a positively skewed distribution. Specifically, $10 \%$ of investors trade very frequently because the top decile of investors (based on their trading frequency) completed a mean number of 69 trades per annum. The second decile traded moderately with 23 trades per annum on average and the remaining $80 \%$ investors traded infrequently at 6 times per annum on average. We argue that this result is not abnormal as other research on trading frequency has found very similar results (Barber \& Odean, 2000; Glaser \& Weber, 2007; Seru et al., 2010; Willows \& West, 2015a). Thus, trading frequently should not be generalised to all investors. The analysis also showed that investors who trade less frequently had a higher proportion of buy trades than investors who traded more frequently. This finding suggests that low frequency traders churn their portfolio to a lesser extent than high frequency traders. 
A second contribution made by this research is that it shows characteristics of investors who trade frequently. Our research indicates that higher trading frequency is associated with male investors, younger investors, investors who trade via the internet and telephone, investors who get advice and investors who use stop losses. These variables are also related as male investors are younger than female investors, investors who trade via the internet are younger than those who do not, investors who use stop losses are younger than those who do not and a higher proportion of male investors use stop losses than female investors. These results complement trading frequency as being younger, male, using the internet to trade and using stop losses all increase trading frequency. However, investors that use the advice team and telephone to trade tend to be older investors, yet older investors trade less than younger investors. These results highlight that relying on demographic variables to predict trading frequency is limited as some older investors, such as those who use the advice team and telephone, trade more frequently than younger investors. Research analyses needs to incorporate these other characteristics to accurately depict which investors trade more than others. Overall, the variables in this analysis explain around $19 \%$ of the variance in trading frequency.

\section{References}

Allen, H., Hawkins, J., \& Sato, S. (2001). Electronic trading and its implications for financial systems. In Electronic finance: a new perspective and challenges (pp. 30-52). http://doi.org/10.2139/ssrn.1187567

Allie, J., West, D., \& Willows, G. (2016). The value of financial advice: An analysis of the investment performance of advised and non- advised individual investors. Investment Analysts Journal, (September), 1-12. http://doi.org/10.1080/10293523.2016.1201292

Baker, H. (2010). Individual Investor Trading. In Behavioral Finance: Investors, Corporations, and Markets (pp. 1-26).

Barber, B. M., \& Odean, T. (2000). Trading Is Hazardous to Your Wealth: The Common Stock Investment Performance of Individual Investors. The Journal of Finance, 55(2), 773-806.

Barber, B. M., \& Odean, T. (2001). Boys will be Boys: Gender, Overconfidence, and Common Stock Investment. The Quarterly Journal of Economics, 116(1), 261-292.

Barber, B. M., \& Odean, T. (2002). Online Investors: Do the Slow Die First? Review of Financial Studies, 15(2), 455-487. http://doi.org/10.2139/ssrn.219242

Barber, B. M., \& Odean, T. (2013). The Behavior of Individual Investors. In Handbook of the Economics of Finance (Vol. 22, pp. 1533-1570). Elsevier B.V. http://doi.org/10.1016/B978-0-44-459406-8.00022-6

Bhandari, G., \& Deaves, R. (2006). The Demographics of Overconfidence. Journal of Behavioral Finance, 7(1), 5-11.

Choi, J. J., Laibson, D., \& Metrick, A. (2002). How does the internet affect trading? Evidence from investor behavior in 401(k) plans. Journal of Financial Economics, 64(3), 397421. http://doi.org/10.1016/S0304-405X(02)00130-7

Daniel, K., \& Hirshleifer, D. (2016). Overconfident investors predictable returns and excessive trading. Journal of Economic Perspectives, 29(4), 61-88.

http://doi.org/10.1017/CBO9781107415324.004 
Daniel, K., Hirshleifer, D., \& Subrahmanyam, A. (1998). Investor Psychology and Security Market Under- and Overreactions. Journal of Finance, 53(6), 1839-1886. http://doi.org/10.2307/117455

Fellner-Röhling, G., \& Krügel, S. (2014). Judgmental overconfidence and trading activity. Journal of Economic Behavior \& Organization, 107, 827-842. http://doi.org/10.1016/j.jebo.2014.04.016

Gervais, S., \& Odean, T. (2001). Learning to Be Overconfident. The Review of Finanicial Studies, 14(1), 1-27.

Glaser, M., \& Weber, M. (2007). Overconfidence and trading volume. Geneva Risk and Insurance Review, 32(1), 1-36. http://doi.org/10.1007/s10713-007-0003-3

Goetzmann, W. N., \& Kumar, A. (2008). Equity portfolio diversification. Review of Finance, 12(3), 433-463. http://doi.org/10.1093/rof/rfn005

Graham, J. R., Harvey, C. R., \& Huang, H. (2009). Investor Competence, Trading Frequency, and Home Bias. Management Science, 55(7), 1094-1106. http://doi.org/10.1287/mnsc.1090.1009

Grinblatt, M., \& Keloharju, M. (2009). Sensation seeking, overconfidence, and trading activity. Journal of Finance, 64(2), 549-578. http://doi.org/10.1111/j.15406261.2009.01443.x

Junor, W. (2014). Men are from Investment Mars and Women are from Investment Venus. The University of Cape Town.

Korniotis, G. M., \& Kumar, A. (2011). Do Older Investors Make Better Investment Decisions? Review of Economics and Statistics, 93(1), 244-265. http://doi.org/10.1162/REST_a_00053

Lind, D. A., Marchal, W. G., \& Wathen, S. A. (2005). Statistical Techniques in Business Economics (Twelfth ed).

Marszalek, B. (2014). Invest Like A Woman: An Analysis of Investment Performance in South Africa based on Gender. The University of Cape Town.

Moore, D. A., \& Healy, P. J. (2008). The Trouble With Overconfidence. Psychological Review, 115(2), 502-517. http://doi.org/10.1037/0033-295X.115.2.502

Nolte, I. (2012). A detailed investigation of the disposition effect and individual trading behavior: a panel survival approach. The European Journal of Finance, 18(10), 885919. http://doi.org/10.1080/1351847X.2011.601635

Odean, T. (1999). Do Investors Trade Too Much? American Economic Association, 89(5), 1279-1298.

Richards, D. W., Rutterford, J., Kodwani, D., \& Fenton-O 'creevy, M. (2015). Stock market investors' use of stop losses and the disposition effect. The European Journal of Finance, 4364(December 2016). http://doi.org/10.1080/1351847X.2015.1048375

Seru, A., Shumway, T., \& Stoffman, N. (2010). Learning by trading. Review of Financial Studies, 23(2), 705-739. http://doi.org/10.1093/rfs/hhp060

Shefrin, H., \& Statman, M. (1985). The Disposition to Sell Winners Too Early and Ride Losers Too Long: Theory and Evidence. The Journal of Finance, 40(3), 777-790. http://doi.org/10.1111/j.1540-6261.1985.tb05002.x

Singh, A., Sandhu, H. S., \& Kundu, S. C. (2010). Investors’ adoption of internet stock 
trading: A study. Journal of Internet Banking and Commerce, 15(1), 1-21.

Willows, G. (2014). Investment Performance of Men and Women as they Age. In The International Symposium on Business and Economics 2014 (pp. 3-15). San Juan, Puerto Rico.

Willows, G., \& West, D. (2015a). Differential Investment Performance In South Africa Based On Gender. International Business \& Economics Research Journal, 14(1), 221236.

Willows, G., \& West, D. (2015b). Differential Investment Performance In South Africa Based On Gender And Age. International Business \& Economics Research Journal, 14(3), 537-560.

Wooldridge, J. M. (2003). Multiple Regression Analysis: Estimation. In Introductory Econometrics: A Modern Approach (p. 71).

Zhang, J., Wang, H., Wang, L., \& Liu, S. (2014). Is there any overtrading in stock markets? The moderating role of big five personality traits and gender in a unilateral trend stock market. PLOS ONE, 9(1), 1-10. http://doi.org/10.1371/journal.pone.0087111 